\title{
Relationships and Dependencies between Discount Methods Used in Capital Budgeting Process in Enterprises
}

\author{
Piotr Tworek
}

Faculty of Economics, University of Economics in Katowice, Poland

Copyright $(\mathcal{C} 2015$ by authors, all rights reserved. Authors agree that this article remains permanently open access under the terms of the Creative Commons Attribution License 4.0 International License

\begin{abstract}
Both in theory and in practice, we can distinguish many financial methods used in the evaluation of investment projects in enterprises. Among them, the most important group constitutes the discount methods, primarily because of their advantages. First of all, they take into account the changing value of money over time. Moreover, knowing not only the advantages but also disadvantages of these methods is a prerequisite for their proper use in practical investment. Knowledge of the mutual relationships and dependencies between these methods is equally important for the success of the investment process. This directly affects the final investment decisions in enterprises, where, in today's practice, on the one hand, the financial viability of projects is being assessed, and, on the other hand, the risks associated with the investment. Therefore, the aim of this paper is to present the methodological problems associated with measuring the financial efficiency of investment projects implemented by the enterprise. In particular, the paper presents both the advantages and disadvantages of discount methods as well as mutual relationships and dependencies between the results of these methods.
\end{abstract}

Keywords Corporate Finance, Capital Budgeting, Investments, Project Evaluation, Discount Methods

\section{Introduction}

'Research conducted by I. Fischer in the early twentieth century on the issues of the investment profitability can be considered as the intellectual foundations and the beginning of the development of financial analysis methodology of many financial issues, including planned investment projects [22]. The concept of Net Present Value (NPV) created then is to the present (after numerous modifications), along with other financial methods, the main criterion for the financial assessment used in the analysis of many phenomena in the world of finance'[22]. Today, however, investors have access to a much broader range of financial methods that can potentially be used in making investment decisions in enterprises. Apart from the traditional methods such as the NPV (Net Present Value), IRR (Internal Rate of Return), MIRR (Modified Internal Rate of Return) and DPP (Discounted Payback Period) more static methods can be used in this field, particularly the simple rates of return, as there are many of them. However, the use of dynamic methods in practical investment is much more important as they provide flexibility in the evaluation of projects with particular emphasis on simulation methods [25] and real options [4], [22]. In contrast with the discount and static methods their application in practice is much more difficult and requires advanced expertise knowledge, especially when it comes to the possibility of using specialised computer software in order to simulate the future performance of investment, including a probabilistic analysis. Particularly useful in this regard may be the Monte Carlo stochastic method of risk simulation [25], which, on the one hand, allows accurately estimate the results of investment, and, on the other, the risks that burden a given investment.

Due to the rapid development of science on finance, the traditional division of methods into static and discount ones should now be replaced with the division into static, dynamic and discount methods. Discount methods are widely used in practice of investment processes in enterprises mainly because of their advantages. Knowledge of both the advantages and disadvantages of each discount method is particularly important at the time of their application in case of every single (individual) project, as there are no two identical projects, and each project has its own individual risk. In particular, this issue is the subject of underlying considerations contained in the paper, and its main purpose is to present the issues of capital budgeting in enterprises, with particular emphasis on methodology concerning the use of discount methods in the evaluation of projects, while indicating their advantages and disadvantages as well as mutual relationships and dependencies that exist between the results of these methods. The paper does not present static methods due to the fact that they do not take into account the changing value of money over time, neither does it show dynamic methods (methods of simulation, real options) 
because their discussion would require a separate study. The paper presents all issues related to its main subject in a synthetic way only. It is mainly theoretical in its character (the theory-cognitive aspect of knowledge) and provides a review of literature on the subject matter. It also refers to part of the results from the empirical studies conducted among 270 largest production companies operating on the Polish market [22]. The research covered the companies from coal mining, power generation, mechanical engineering, automotive, construction, IT, metallurgic and fuel industries [22]. Questionnaires were also sent to blue chip companies listed on the Warsaw Stock Exchange as well as the selected state-owned enterprises [22]. All the formulas given in the paper are taken from literature [1], [2], [3], [5], [6], [7], [8], [9], [12], [13], [15], [17], [26], [27], [28], [29], [33], [38]. Induction, deduction, and the method of synthesis are used here. Also the utilitarian advantages of the presented discount methods are stressed in the paper.

\section{Capital Budgeting Process in Enterprises}

It follows from the theory of finance that the essential criterion for the division of methods used in the financial evaluation of investment projects in enterprises is the changing value of money over time. For capital has a different value in different time intervals, hence there is a need for discounting, which is inextricably linked to the category of the discount rate as one of the many interest rates in finance. Directly connected with this is also the name itself of discount methods (NPV, IRR, DPP) or, for example, (discount) models used in the process of share valuation of enterprises (Gordon model and others) [14]. Thus, discounting is the foundation for project evaluation processes, and the assessment of financial performance of investments is based on the current values of the PV (Present Value), whereat the future values of FV (Future Value) of capital are characterised by decreasing present value [35]. First of all, in the discounting process it should be kept in mind that both in theory and in practice there are different approaches to the selection and the method of estimating the discount rate. As highlighted in the introduction, directly with this issue is related a new division of financial methods in the literature into discount, dynamic and static methods, whereas the static methods are often not used in practice and are commonly referred to as primitive measures of investment efficiency. Among them there can be identified accounting rates of return where currently there are as many as several algorithms for estimating the ARR (Accounting Rate of Return) [29] or, for example, a simple rate of return the ROI (Return on Investment). It should be made clear once again that the lack of flexibility characteristics needs to be considered as an essential criterion for the division of methods into dynamic and discount ones. Therefore, a kind of superiority of dynamic methods over the discount ones [35], [37] is often emphasised in the literature. Besides the traditional approach to assessing the profitability of investment, net cash flows $\mathrm{CF}$ for some of the projects are determined on an ex-ante basis, which means that traditional discount methods take into account the future changes in this regard, thus making it impossible to limit the risk effectively [22]. The empirical studies carried out in this respect 'in Poland show that $26 \%$ of the companies surveyed apply only simple methods when evaluating the return on specific investment projects, $32 \%$ limit themselves to discount methods exclusively and $39 \%$ of the companies combine both kinds of methods although simple methods are perceived as supporting ones' [29].

'Since the investment processes occur in conditions of risk, hence the current view that taking into account the risk in the traditional approach to cost-effectiveness calculations (for some projects) is not enough' [22]. This primarily stems from the fact that the analysis of investment projects concerns the future, which by its nature is uncertain and is based on, firstly, estimated stream of net cash flows, secondly, determining the value of the discount rate as the imputed rate, thirdly, the use of specific financial methods (calculations of algorithms) to estimate the expected financial performance of investment, fourthly, estimating the risk for investment, fifthly, making the right investment decisions on the basis of calculations (results) [35]. These listed elements are, at the same time, a simplified description of the capital budgeting process in the enterprise, however it should always be keep in mind that the profitability of investment does not need to be based on profit as an economic category, but on cash flows $\mathrm{CF}$, and that any mistakes in the calculation of $\mathrm{CF}$ or in the estimation of discount rate $r$, will provide erroneous end results of the investment [35]. The simplified capital budgeting process in the enterprise is presented in Figure 1. 


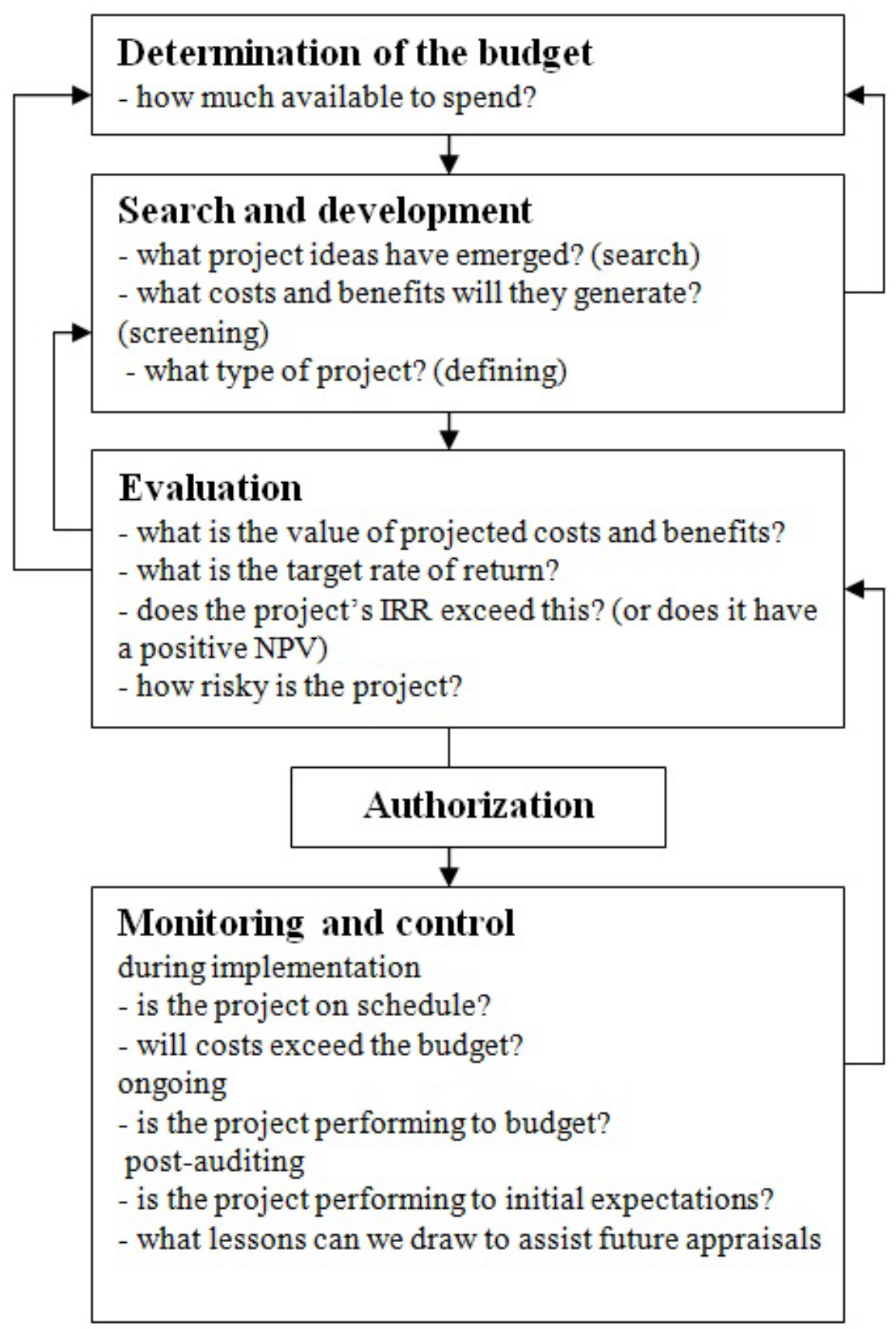

Figure 1. A simple capital budgeting system. Source: [27]

Generally, Figure 1 shows that the capital budgeting process in the enterprise is a four-phase procedure and consists of, firstly, 'the determination of the budget, which includes a decision on the available amount possible to be spend on financing projects, secondly, research and development, which involves the identification of project proposals, their preliminary assessment and a preliminary definition of projects, thirdly, the evaluation and authorization of the project, which consists of a detailed study of the project, including an assessment of cost-effectiveness and risk as well as making a formal decision on implementation or rejection, improvement or bringing the project to a temporary halt, fourthly, monitoring and control, which means monitoring project implementation and a post-audit during the lifetime of the project' [22], [27]. Regardless of the way of defining, structure and the course of capital budgeting process, the most important all of this is the purpose for which the investments are made in enterprises. The goal is to maximize the value of the enterprise [10] and one way to achieve this is the implementation of investments [16].

Analysing Figure 1, a basic conclusion can be drawn that investments which contribute greatly to maximizing enterprise's value, and which, in turn, should mean an increase in its balance-sheet total ought to always be chosen. At the same time, the increase in value should be reflected in the increase in share prices of enterprises listed on the stock exchange. The relationship between undertaken projects in 
enterprises and the creation of value in an entity is illustrated by the following formula:

$$
N P V=\sum_{t=1}^{n} \frac{E V A_{t}}{(1+W A C C)^{t}}
$$

Where $\mathrm{EVA}_{\mathrm{t}}$ is the Economic Value Added generated by the project in year $t$ and the WACC is the Weighted Average Cost of Capital necessary to finance the investment in the enterprise. Thus, the increase in the value of the entity can be achieved by implementing effective investments in the financial terms, namely investments that bring economic profit when the rate of return on the investment is higher than the rate of return required by an investor engaging capital in it [7], [8]. Hence, the NPV of the project equals the present value of the EVA generated in the future or the EVA for every year $t$ (discounted) is a certain part of the specified whole, i.e. the total NPV [7], [8]. The Economic Added Value EVA is determined in the below formula as follows:

$$
\mathrm{EVA}_{\mathrm{t}}=\mathrm{NOPAT}_{\mathrm{t}}-\mathrm{WACC}_{\mathrm{t}} \cdot \mathrm{IC}_{\mathrm{t} \text { BEG }}
$$

Where $\operatorname{NOPAT}_{t}$ is the Net Operating Profit After Tax for year $t$, and the $\mathrm{IC}_{\mathrm{tBEG}}$ is the capital invested in the enterprise's assets (book value of the opening balance of year $t$ ) [7], [8]. In contrast, the formula for WACC, which is the Weighted Average Cost of Capital in year $t$, is as follows:

$$
W A C C=\sum_{i=1}^{Z} w_{i} c_{i}
$$

Where $z$ is the number of capital sources, $\mathrm{w}_{\mathrm{i}}$ is the share of a specific origin of capital for financing investment, while $c_{i}$ is the cost of capital coming from a specific source [27]. This formula undergoes modification depending on how many sources of funding for the project the investor has to deal with and on what is the share of individual sources in the overall structure of investment financing. For example, in case of investment in the enterprise by the purchase of the property, assuming that the project will be financed from two sources, i.e. a mortgage and own resources of the investor [36], the WACC formula is as follows:

$$
W A C C=C_{b} w_{1}+C_{e} w_{2}
$$

Where $\mathrm{w}_{1}$ means the share of bank credit in the total resources earmarked to finance the project, $\mathrm{w}_{2}$ is the share of investor's own funds in the overall funds intended to finance the project, $\mathrm{C}_{\mathrm{e}}$ is the cost of equity, whereas $\mathrm{C}_{\mathrm{b}}$ means the cost of equity from a bank loan or foreign sources, and the formula for the cost of capital coming from bank loans is as follows:

$$
C_{b}=i(1-T)
$$

Where $i$ is a bank interest rate, which is the nominal interest rate, and $\mathrm{T}$ is the income tax rate. In Poland, the income tax rate for enterprises is $19 \%$. 'Attention should be drawn here to the findings of the empirical research, where $70 \%$ of the surveyed Polish companies adopt the cost of capital approach when estimating the discount rate value, while the other enterprises (30\% of the respondents) apply the expected rate of return method e.g. using the beta coefficient as a measure of risk' [29]. In summary, the WACC formula is very important both in the theory of corporate finance and in business practice, as, inter alia, it can be used to calculate the discount rate in the NPV method. Then the formula for the NPV is as follows:

$$
N P V=\sum_{t=0}^{n} \frac{C F_{t}}{(1+W A C C)^{t}}-C E_{0}
$$

Where $\mathrm{CE}_{0}$ means the total investment expenditure on the project in the enterprise, and $\mathrm{CF}_{\mathrm{t}}$ is the net cash flow in year $t$, which, in turn, is expressed by the following formula:

$$
C F_{t}=(1-T)(S-C-D)+D
$$

Where $\mathrm{S}$ is sales revenue, $\mathrm{C}$ is the running costs but without depreciation and amortization, $\mathrm{T}$ is the income tax rate, $\mathrm{D}$ is depreciation, while $t$ is the period (year) of analysis [27]. Thus, in practice, if the capital expenditure is incurred in the subsequent years of investment analysis, then the general formula for the NPV is converted to the form:

$$
N P V=\sum_{t=0}^{n} \frac{C F_{t}}{(1+r)^{t}}-\sum_{t=0}^{n} \frac{C E_{0}}{(1+r)^{t}}
$$

Where $r$ is the discount rate, $n$ is the period of investment analysis, $\mathrm{CE}_{0}$ means the total investment expenditure incurred in the subsequent years of project analysis (which in particular can be related to megaprojects, the implementation of which lasts many years). In big-scale projects, it's important to estimate the value of the discount rate correctly. Any mistakes at this stage can cause erroneous determination of the NPV and IRR results and the estimation of the investment risk. Thus, the investor will give the wrong answers to the questions contained in Figure 1, and, in particular, will not reach the higher rate of return on more risky investment [20], [27], [30], [32]. In case of high-risk projects 'calculating the financial efficiency of investment using the NPV method and accounting for the risk, the procedure is as in conditions without risk, and the only change is to replace the risk-free discount rate (expressing the time value of money) with the rate taking into account the time value of money and the risk of the project, which is the RADR rate' [22]. Then, a modified form of the general formula for the NPV is as follows:

$$
\mathrm{NPV}_{R A D R}=\sum_{t=0}^{n} \frac{C F_{t}}{(1+R A D R)^{t}}
$$

Where RADR is a discount rate including a project risk [22]. In case of investment in an enterprise in financial assets (securities) in order to estimate the discount rate considering the risk, it's possible to use the CAPM model (Capital Asset Pricing Model), the formula is as follows:

$$
r_{e}=r_{f}+\left(r_{m}-r_{f}\right) \beta
$$

Where $r_{e}$ is the cost of equity capital, $r_{f}$ is the risk-free rate of return, $r_{m}$ is the market return (return on the market portfolio of assets), whereas the coefficient $\beta$ is a measure of the relative market risk, and its interpretation is as follows: if 
the coefficient $\beta>1$ then the investment risk is greater than average in a given market, and when the $0<\beta<1$ then the investment risk is lesser than the average market [27]. Today, all modern theories of investment in the capital market take into account the element of risk [4], [19], [23], [24], [31], while not ruling out the behavioural aspects of investing [17], [34]. 'The largest Polish companies surveyed differ in the way they use specific quantitative methods in risk management for investment projects [22]. In as many as $65 \%$ of the companies risk quantification is part of their feasibility studies [22]. The remaining ones $(35 \%$ of the surveyed companies) do not quantify risk when evaluating the profitability of investment projects [22]. The discount rate adjustment turns out to be a fairly popular method [22]. Although no respondents declare the use of the method on a day-to-day basis, $46 \%$ of the largest companies operating in Poland use it 'frequently' and $15 \%$ 'occasionally' [22].

It should be noted that these are very important issues from a theoretical point of view, however in business practice answering the question what is the NPV for the project (Figure 1) there is a commonly used approach for the calculation of the discount rate in accordance with the following formula: risk-free interest rate + risk premium [27]. 'Its application in practice is primarily due to the fact that projects are implemented under various sectors of the economy. Thus, they are subject to lesser or greater degree of risk. The investor compensates this risk by calculating a higher interest rate (risk premium), which then adds to the risk-free rate, which, inter alia, in Poland, is represented by Treasury Bills, hence the financial instruments which in the theory of finance are considered to be risk-free' [36]. In conclusion, generally an enterprise creates value for shareholders when:

$$
\text { ROIC > WACC }
$$

Where the ROIC is the achieved rate of return on invested total capital (own and borrowed), whereas inequality (11) is an essential condition of investment efficiency, which means that the return on investment should be greater than the rate reflecting the cost of capital employed in financing the investment [33]. However, it should be kept in mind that there are many rates of return and inequality (11) may be modified, where in practice the investor frequently assumes that IRR > WACC, or MIRR > WACC, which means then that the project is financially viable [37]. To sum up, we can also distinguish two basic criteria for investment decision-making in enterprises, i.e. firstly, the criterion of absolute benefits or the criterion of absolute benefit increase measured by the PV value or increase in the NPV, secondly, the criterion of relative benefits, measured by the Internal Rate of Return IRR [21]. In particular, further considerations are devoted to those two decision-making criteria, mainly because of the mutual relationships and dependencies between the results of the NPV and IRR methods, and also due to the fact that the discount rate is the basic parameter used in discounting methods for evaluating the effectiveness of investments based on cash flows CF [27], [37].

\section{Mutual Relationships and Dependencies between Discount Methods Used in Project Evaluation in Enterprises}

Both in theory and in practice, the fact that there are strong relationships between the values created in the enterprise is emphasized. One of these fundamental values is the NPV which determines the increase in enterprise's value from the implemented project. At the same time, thanks to the NPV method, 'it's possible to specify how large is the increase in enterprise's value due to implementation of several projects at the same time [16]. The NPV method characteristic is the possibility of aggregation of individual values of the NPV project results [16]. This also has a direct relationship with the type of investment decision taken, which commonly distinguishes the division into investment decisions on individual projects, mutually exclusive, or on the entire portfolio of projects [16]. Because, in the enterprise, all investment decisions made create an overall picture of its investment policies, then one would assume that the level of the implementation can be measured by the results of the NPV of total projects undertaken [16]. In other words, the framework of chosen investment policy pursued by the projects will delimit the possible maximum or minimum total result of the NPV of all projects in the enterprise' [16]. The other advantages of the NPV method against both the benefits and drawbacks of other discount methods used in the capital budgeting process in enterprises are presented in Table 1 (Appendix).

Among the discount methods listed in Table 1, the NPV method has only advantages. The other methods, including the MIRR and the PI (Profitability Index), have limitations that have already been identified. There are close dependencies and relationships among these methods, which directly follow from the definition of IRR, which is such a discount rate at which the NPV result is 0 . This relationship is described by the following formula:

$$
\sum_{t=0}^{n} \frac{C F_{t}}{(1+I R R)^{t}}-C E_{0}=0=N P V
$$

The IRR result as expressed in the form of interest rate return on the investment under assessment, or it can be defined in a different way, namely it is the discount rate at which the present value of cash flows (investment income) is equal to the present value of cash expenditure related to the construction and operation of the project investment [35], which can be illustrated as the following equation [27]:

$$
\sum_{\mathrm{t}=0}^{\mathrm{n}} \frac{\mathrm{CIF}_{\mathrm{t}}}{(1+\mathrm{IRR})^{\mathrm{t}}}=\sum_{\mathrm{t}=0}^{\mathrm{n}} \frac{\mathrm{COF}_{\mathrm{t}}}{(1+\mathrm{IRR})^{\mathrm{t}}}
$$

Since the IRR is expressed as a percentage, it corresponds to the rate at which the project allows the return on investment expenditure [34]. Therefore, another relationship occurs here, i.e. between the IRR and the DPP [34], which can be written as follows [27]:

$$
D P P=\frac{1}{I R R}
$$


In equation (14) the DPP results from the following formula [3]:

$$
D P P=t+\frac{W_{t}}{C F_{t+1}}
$$

Where $t$ means the last year, at the end of which the investment expenditure has not been paid back to the investor, $\mathrm{W}_{\mathrm{t}}$ is the investment expenditure not paid back in year $t$, and $\mathrm{CF}_{\mathrm{t}+1}$ is the net revenue generated by the project in the next year, that is $t+1$. In particular, 'the relationship described by equation (14) can be interpreted as follows: the higher rate of return of the project, the quicker pay back' [27]. However, in order to eliminate assumptions about the reinvestment rate equal to the IRR, the internal rate of return is modified to the form of MIRR (Modified Internal Rate of Return), which shows the following mathematical notation [27]:

$$
M I R R=\frac{\sqrt[n]{\sum_{t=0}^{n} C I F_{t}(1+r e i)^{n-t}}}{\sqrt[n]{\sum_{t=0}^{n} C O F_{t}}(1+\mathrm{r})^{\mathrm{t}}}-1
$$

Where rei is the rate of capital reinvestment. From equation (16) it becomes apparent that the MIRR, like the IRR, is defined as the discount rate that equalises the updated residual value of the project with the updated value of investment expenditure incurred [35]. In addition to the NPV, IRR, MIRR and the DPP, Table 1 indicates the advantages and disadvantages of the PI ratio. For the project to be financially viable the PI ratio must be at least equal to or be greater than 1 . This ratio along with its modified form of the MPI informs investors how many monetary units will be generated by the project as a result of incurring the unit of the investment expenditure, which in mathematical form expresses the following formula :

$$
P I=\frac{P V}{C E_{0}}
$$

Where the PV in a simplified formula for the NPV is as follows:

$$
P V-C E_{0}=N P V
$$

The NPV profile for various projects is graphically illustrated by Figures 2, 3 and 4, which at the same time represent the multi relationships and dependencies between the NPV and IRR.

\section{$N P V$}

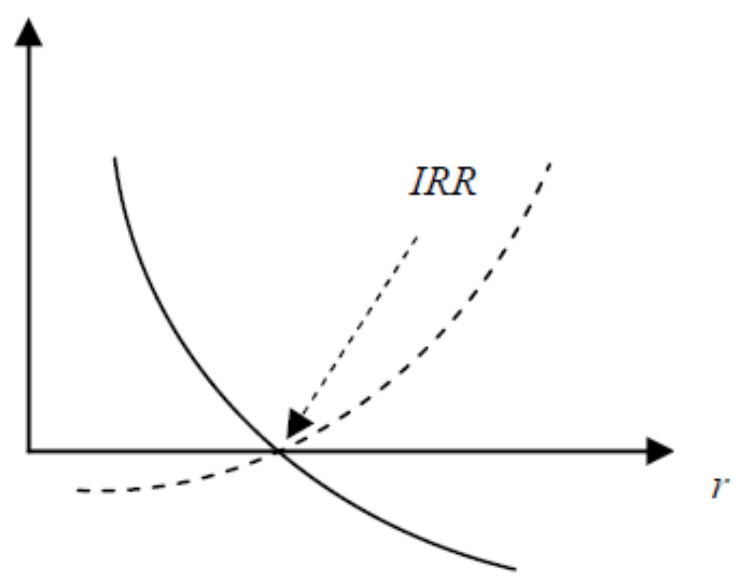

Figure 2. Relationships between NPV and IRR. Source: [3], [28], [29].

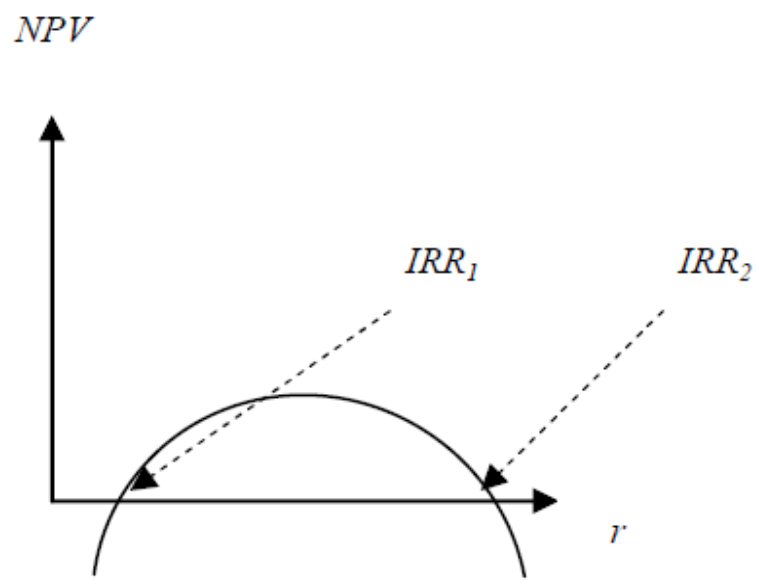

Figure 3. Relationships between NPV and IRR. Source: [3], [28], [29].

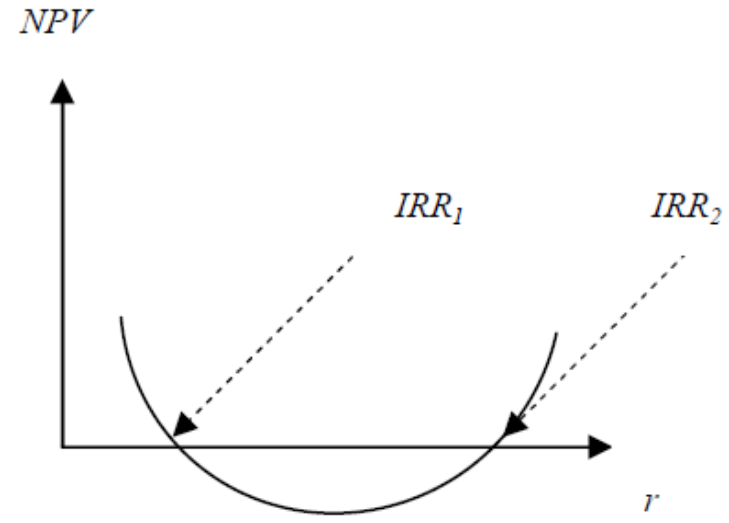

Figure 4. Relationships between NPV and IRR. Source: [3], [28], [29].

Figures 2, 3 and 4 show different profiles of the NPV calculated for various projects (broken down into typical and non-typical projects) with the value of the discount rate $r$. In particular, Figure 2 shows the profile of a typical NPV for the project, so investments that generate conventional stream of 
cash flows $\mathrm{CF}$, i.e. such projects, which in practice have one IRR rate and are viable from the financial point of view, that is NPV $>0$. Then, the IRR is also greater than the rate that expresses the cost of capital needed to finance the investment, or IRR > WACC (in this case enterprise's investment activity is financed from at least two different sources at a time) [35]. In case of a typical investment, the IRR can be estimated using the universal linear interpolation formula in this regard [27], namely:

$$
I R R=r_{0}+\frac{N P V_{0}}{N P V_{0}-N P V_{1}}\left(r_{1}-r_{0}\right)
$$

Where $r_{0}$ is a lower discount rate accepted for the calculation, $r_{l}$ is a higher discount rate accepted for the calculation, the $\mathrm{NPV}_{0}$ is the NPV result calculated at a lower discount rate, the $\mathrm{NPV}_{1}$ is the NPV result calculated at a higher discount rate [3]. The application of equation (19) is common in the practice of investing, and the substance of the use of this formula lies in the calculation of the NPV results for the investment at a given value at two discount rates $r_{0}$ and $r_{l}$, until the mathematical function that reflects the NPV result changes from positive to negative (Figure 2), namely the NPV changes its sign from positive to negative or from negative to positive (dotted line in Figure 2). Generally, the IRR estimation is to find the zero-value of the function (Figure 2). On the other hand, Figures 3 and 4 show the NPV profile for non-typical projects, which have unconventional stream of net cash flows. At the same time, Figures 3 and 4 show projects that have two parallel IRR rates (in theory there may be three or more, because the lifetime of the investment can be stretched to $+\infty$ ), namely in case of Figure 3 , if the cost of capital expressed by rate $r$ is known then $I R_{1}<r$, and $I_{R R}>r$ [35]. This means that the IRR method has a major drawback, namely, it is unreliable in case of investments with unconventional stream of net cash flows and it should not be used in practice for this type of projects [35]. In addition, it is unreliable for establishing a hierarchy of projects that vary in scale and size of the investment lifetime. In case of projects in Figures 3 and 4, the NPV as the main criterion for decision-making should be used, as this method does not have drawbacks (Table 1).

Theoretically, there is also a situation in which the IRR for a given investment cannot be estimated at all. This is illustrated in Figure 5.

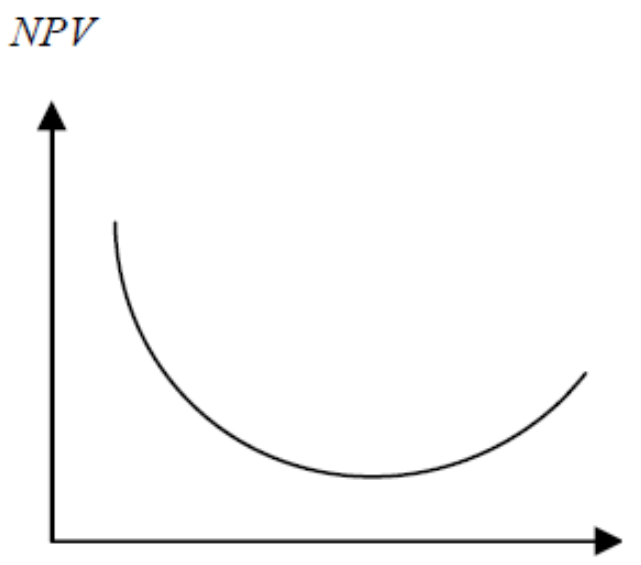

Figure 5. Non-typical project without IRRs. Source: [3], [28], [29].

Figure 5 also shows an example of a non-typical investment. This investment is simply unprofitable, which means that the investment expenditure incurred by the investor is not going to pay off at all, and thus neither can the DPP result be determined, nor the MIRR be calculated. In practice, the enterprise should abandon implementing such a project. At the same time, it should be added that in business practice all depends on the way of investment, the sources of funding, the size of the project, the lifetime of the investment, the size of the risk carried by a given project, etc. Therefore, the NPV and IRR for different projects are calculated differently, i.e. appropriate modifications to the formulas should be made in this case. The financial effectiveness is calculated differently for investments in real estate market and differently for large industrial and commercial undertakings, and yet quite differently in case of public sector projects, where the CBA analysis (Costs-Benefits Analysis) is applicable as a counterpart to the NPV method in the commercial sector. Differently are also estimated final results for small projects and differently for, for example, megaprojects. There is always a need to adapt a given method to a specific situation, including the investor's expectations. For example, in case when there is one-off income from the investment, the IRR formula is converted to the following form:

$$
I R R=\sqrt[t]{\frac{C F_{t}}{C E_{0}}}-1
$$


There is also a possibility that, hypothetically, the investor will receive a fixed income of infinite duration from investment, which also requires the conversion of equation (12) into a modified form. Then the IRR for investments is specified by the following formula:

$$
I R R=\frac{C F_{i s}}{C E_{0}}
$$

Where $\mathrm{CF}_{\text {is }}$ is a fixed income of infinite duration generated by the project. The general rule is, however, that 'in practice, the use of discount methods should be done in a comprehensive and complementary manner regardless of the type and specificity of the project, and the selection of the risk measurement method [35]. This is particularly important when the investor ranks projects which differ in size of capital expenditure or the period over which income from investments is generated, and which have an unconventional stream of net cash flows, i.e. in case when the project portfolio is non-typical [35]. The decision-making situation for selecting one of two projects in the enterprise is graphically illustrated in Figure 6.

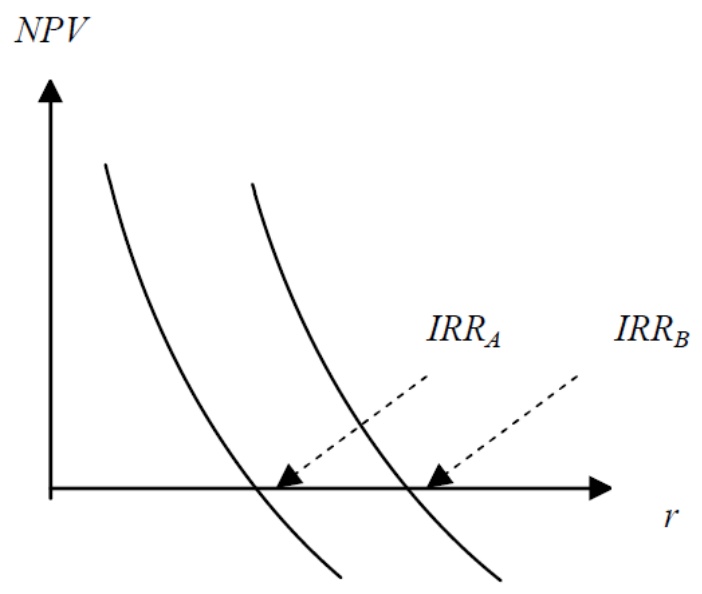

Figure 6. Projects of the same size and lifetime Source: [18], [28], [29].

In particular, Figure 6 shows the decision-making situation in which the investor has chosen one of two projects which do not differ in size and lifetime. In such a situation, the decision-making choice is easy, i.e. the project with a higher NPV is to be chosen. The situation is similar when the investor has a portfolio of typical projects and has chosen one of the many feasible projects [35]. Then the investment decision is equally easy i.e. the project with the highest NPV is to be chosen [35]. However, in a situation when two projects are mutually exclusive and differ in the size of investment expenditure, then it may be the case that for one project with a higher NPV the IRR result may be lower in comparison with the second project, of which the NPV result is lower, but it has a higher IRR [35]. This situation is shown in Figure 7.

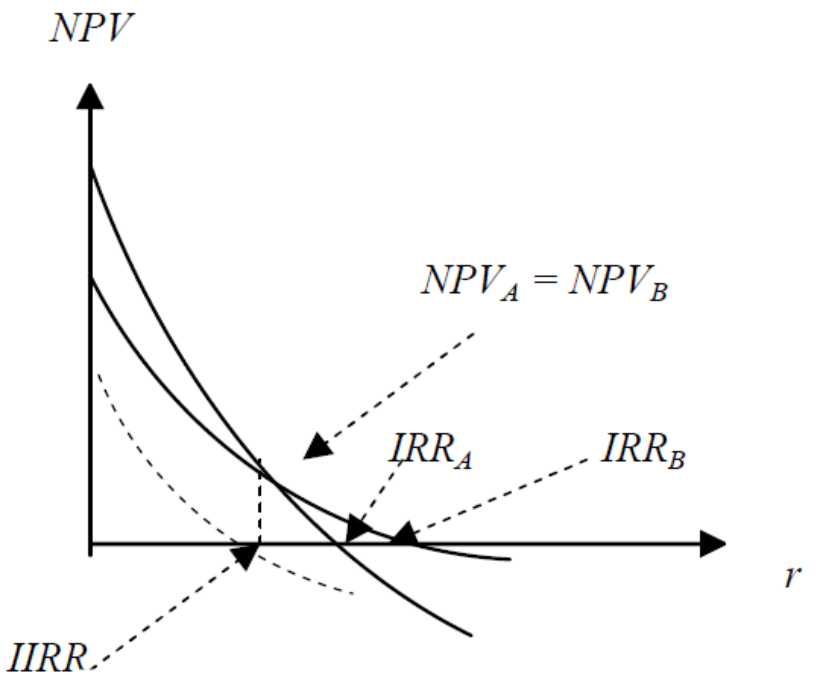

Figure 7. Mutually exclusive projects and of different size Source: [18], [28], [29].

As it can be seen in Figure 7 'the NPV curves of the analysed $\mathrm{A}$ and $\mathrm{B}$ projects cross when $\mathrm{r}=\mathrm{IIRR}$, where the IIRR stands for the Incremental Internal Rate of Return (IIRR)' [18], i.e. it is such a discount rate (cost of capital) at which the NPVs of competitive projects are equal [18]. In the event the investor has to choose one out of the projects shown in graph B (Figure 7), then 'if the cost of capital is higher than the IIRR, then project A should be chosen as it has a higher NPV and IRR. If the cost of capital is lower than the IIRR, then project B should be selected as it has a lower IRR but a higher NPV (for this $r$ )' [18]. Such situations are particularly difficult in practical investing.

\section{Conclusions}

An integral part of corporate financial management is pre-investment analyses made in enterprises all over the world. As part of the capital budgeting process, the final outcome for projects in enterprises is estimated. These calculations relate to the future, and, therefore, are subject to risk. Hence, the literature often emphasizes the distinction between investment decisions made under the conditions of uncertainty and risk [1]. Therefore, every decision regarding the future is associated with bearing the risk [11]. 'Analysis of the literature indicates that individual authors, although differing in detail, are unanimous as to the nature and purpose of capital budgeting in the enterprise [22]. Without going into an analysis of the specific approaches of authors, it can be stated that capital budgeting is a multistep process in which the investment risk is a fundamental category of consideration, however the methodical approach to the risk changes at different stages due to the subject matter of the research and the purpose of a given stage [22]. In particular, the objective of capital budgeting is, on the one hand, to ensure that the available capital resources of the enterprise were distributed between generating value projects so as they best contribute to achieving the objectives of that enterprise, 
and on the other hand, obtaining the belief that good investment ideas will not be ceased and adverse or ill-defined ideas will be rejected or fine-tuned' [22]. In general, it should be noted that, firstly, regardless of the financial method used in the capital budgeting, attention should be paid to all possible results obtained, i.e. not only to the results of discount methods, but also the results of the applied simple methods; secondly, all methods listed in Table 1 (Appendix) should be used complementarily and only on this basis the right investment decisions should be made; thirdly, lack of flexibility of discount methods is no barrier, which precludes their use in business practice on a large scale; fourthly, taking appropriate investment decisions in the enterprise, apart from the key measures of financial performance, the investment risk should always be evaluated; fifthly, in capital budgeting process, the advantages and disadvantages of each discount method should always be kept in mind; sixthly, the valuation results by discount methods largely depend, on the one hand, on the accuracy of the adopted discount rate $r$, and, on the other hand, the accuracy of cash flow forecasts $\mathrm{CF}$, namely making mistakes at this stage will contribute to erroneous results of the final calculation, which consequently, will result in making wrong investment decisions; seventhly, the effects of investment decisions should be separated from the effects of decisions relating to the project funding; eighthly, the return on investment analysis should be based on cash flows, not on profit, and the analysis of cash flows should be incremental, where the opportunity costs (costs of lost benefits) should also be taken into account, thus the cash that will actually not be incurred or generated in case of implementing the investment, and yet they should be taken into consideration when examining the financial efficiency of the investment; ninthly, the impact of the project on the cash flows arising in other divisions of the enterprise should always be taken into account; tenthly, the fact that the effects of investment decisions can be visible only after many years should always be kept in mind, and the decisions of this type generally stimulate the development of the enterprise and, above all, contribute to the creation of its value; finally, the implications of erroneous investment decisions should be taken into account, which, in the worst case scenario may even bring the enterprise to the edge of bankruptcy [35]. Therefore, bankruptcy is the worst consequence of poor investment decisions taken in the enterprise. 'All this is set against the background of current market conditions worldwide. According to $60 \%$ of the surveyed largest companies in Poland the present economic crisis has not affected the value of the discount rate they use [22]. However, $40 \%$ of the companies claim that the current economic situation in Poland has had a considerable impact on the value of the discount rates they use' [22]. A rise in interest rates in an economy inevitably means a rise in the cost of capital.

\section{Acknowledgements}

In the paper, the author used his own knowledge and experience which he has acquired in both business practice and scientific work at the University of Economics in Katowice, Poland.

\section{Appendix}

Table 1. The most important advantages and disadvantages of discount methods used in capital budgeting. Source: [29]

\begin{tabular}{|c|c|c|c|c|c|c|}
\hline Method & $\begin{array}{c}\text { Takes into } \\
\text { account entire } \\
\text { project lifecycle }\end{array}$ & $\begin{array}{c}\text { Takes into } \\
\text { account } \\
\text { changeable } \\
\text { time value of } \\
\text { money } \\
\end{array}$ & $\begin{array}{l}\text { Takes into } \\
\text { account } \\
\text { company's } \\
\text { objectives }\end{array}$ & $\begin{array}{c}\text { Takes into account } \\
\text { project risk }\end{array}$ & $\begin{array}{c}\text { Determines net } \\
\text { gains as net } \\
\text { cash flows }\end{array}$ & $\begin{array}{c}\text { Possibility of } \\
\text { constructing an } \\
\text { objective } \\
\text { decision-making } \\
\text { criterion } \\
\end{array}$ \\
\hline NPV & Yes & Yes & Yes & Yes & Yes & Yes \\
\hline $\begin{array}{c}\text { MNPV } \\
\text { (modified NPV) }\end{array}$ & Yes & Yes & Yes & Yes & Yes & Yes \\
\hline IRR & Yes & Yes & No & Yes & Yes & Yes \\
\hline MIRR (modified IRR) & Yes & Yes & No & Yes & Yes & Yes \\
\hline PI & Yes & Yes & No & Yes & Yes & Yes \\
\hline MPI (modified PI) & Yes & Yes & No & Yes & Yes & Yes \\
\hline DPP (discounted) & No & Yes & No & Yes & Yes & No \\
\hline
\end{tabular}




\section{REFERENCES}

[1] Aggarwal R. Capital Budgeting under Uncertainty. New Jersey: Prentice - Hall, Inc. 1993.

[2] Arnold G. Corporate Financial Management. $6^{\text {th }}$ Ed. Edinburgh - Harlow - Essex: FT Prentice Hall. 2002.

[3] Behrens W., Hawranek M.P. Poradnik Przygotowania Przemysłowych Studiów Feasiblity. Warszawa: United Nations Industrial Development Organization (UNIDO). 1993.

[4] Black F., Scholes M. The pricing of options and corporate liabilities. Journal of Political Economy. 1973; 81: pp. 637-659.

[5] Brealey R., Myers S., Allen F. Principles of Corporate Finance. $8^{\text {th }}$ Ed. New York: McGraw-Hill Irwin. 2006.

[6] Brealey A.R., Myers C.S., Marcus J.A. Fundamentals of Corporate Finance. $5^{\text {th }}$ Ed. New York: McGraw-Hill, Inc. 2007.

[7] Cwynar A., Cwynar W. Mierniki kreowanej wartości spółki kapitałowej. (Eds.) Szablewski A., Tuzimek, R. Warszawa: Poltext. 2004.

[8] Cwynar A., Cwynar W. EVA a kreacja wartości dla akcjonariuszy. Przegląd Organizacji. 2004; No. 1: 32.

[9] Brigham F.E., Gapenski C.L. Zarządzanie Finansami. Warszawa: PWE. 2000.

[10] Dallas F.M. Value \& Risk Management. Oxford: Blackwell Publishing. 2006.

[11] Drucker P. Managing for results: economic tasks and risk-taking decisions. London: Heinemann. 1964.

[12] Gitman J.L. Principles of Managerial Finance. $11^{\text {th }}$ Ed. Boston: Pearson Education, Inc. 2006

[13] Gitman J.L., Joehnk D.M., Smart B.S. Fundamentals of Investing. $11^{\text {th }}$ Ed. Boston: Pearson Education Limited, Inc. 2011.

[14] Gordon M. Dividends, Earnings and Stock Prices. Review of Economics and Statistics. 1959; 41 (2): 99-105.

[15] Hartman C.J. Engineering Economy and the Decision-Making Process. New York: Pearson Education, Inc. 2007.

[16] Henzel H., Tworek P. Polityka inwestycyjna przedsiębiorstwa wyznacznikiem wzrostu jego wartości. Ed. Henzel H. Katowice: Wydawnictwo Akademii Ekonomicznej. 2007, pp. 33-34.

[17] Hirschey M., Nofsinger J. Investments: Analysis and Behaviors. Fundamentals of Corporate Finance. New York: McGraw-Hill Companies, Inc. 2008.

[18] Jajuga K., Jajuga T. Inwestycje: instrumenty finansowe, aktywa niefinansowe, ryzyko finansowe, inżynieria finansowa. Warszawa: PWN, 2007, p. 366.

[19] Kahneman D., Tversky A. Prospect theory: An analysis of decision under risk. Econometrica. 1979; 47: pp. 313-327.

[20] Loosemore M., Raftery J., Reilly Ch., Higgon D. Risk Management in Projects. New York - London: Taylor \& Francis. 2006.

[21] Marciniak Z. Zarządzanie wartością i ryzykiem przy wykorzystaniu instrumentów pochodnych. Warszawa: Szkoła Główna Handlowa. 2004, p. 14.

[22] Marcinek K., Foltyn M., Pera K., Saługa P., Tworek P. Ryzyko w finansowej ocenie projektów inwestycyjnych: wybrane zagadnienia. Katowice: Wydawnictwo Uniwersytetu Ekonomicznego. 2010, p. 9, 11, 46, 47, 74.

[23] Merton R. On the pricing of corporate debt: The risk structure of interest rates. Journal of Finance. 1973; 6: pp. 449-470.

[24] Miller M., Modigliani F. Dividend Policy, Growth and the Valuation of Shares. Journal of Business. 1962; 34: 411-433.

[25] Molak V. Fundamentals of Risk Analysis and Risk Management. Boca Raton: CRC Press LLC. 1997.

[26] Nersesian L.R. Corporate Financial Risk Management. A Computer-Based Guide for Nonspecialists. Westport: Praeger Publishers. 2004.

[27] Pike R., Neale B. Corporate Finance and Investment. Harlow: Pearson Education Limited, Inc. 2003.

[28] Pluta W. Budżetowanie kapitałów. Warszawa: PWE, 2000.

[29] Rogowski W. Rachunek efektywności przedsięwzięć inwestycyjnych. Kraków: Oficyna Ekonomiczna, 2008.

[30] Schuyler J. Risk and Decision Analysis in Projects. Newtown Square: Project Management Institute. 2001.

[31] Sharpe W. Capital Asset Prices: A Theory of Market Equilibrium under Conditions of Risk. The Journal of Finance. 1964; XXIV (4): 425-442.

[32] Smirlock M., Yawitz J. Asset Returns, Discount Rate Changes, and Market Efficiency. The Journal of Finance. 1985; XL (4): $1141-1158$

[33] Szablewski A. Zarządzanie wartością firmy. Istota i kierunki ewolucji. Warszawa: Poltext. 2000, p. 16.

[34] Tworek P. Behavioural aspects of risk management in investment processes in construction. Ed. Čulik M. Ostrava: VŠB - TU Ostrava. 2014.

[35] Tworek P. Capital budgeting in enterprises: mutual relationships and dependencies between discount methods used in project evaluation. Bratislava: Ekonomická Univerzita v Bratislave. 2014, pp. 278-287.

[36] Tworek P. Selected aspects of the investment decision-making process in Polish corporations - a methodical approach. Ed. Dluhošová D. Ostrava: VŠB - TU Ostrava. 2009.

[37] Tworek P. The investment decision-making process in entrepreneurship: advantages and disadvantages of selected financial methods used in projects evaluation. (PART III). Ed. by Čulik M. Ostrava: VŠB - TU Ostrava. 2013, pp. 995-996.

[38] Watson D., Head A. Corporate Finance. Principles \& Practice. $5^{\text {th }}$ Ed. Harlow: Pearson Education Limited Inc., 2007. 